\title{
Indonesian Customer Attitude Towards Green Hotels
}

\author{
Purnomo ${ }^{1, *}$ Ratih Hurriyati ${ }^{2,}$ Heny Hendrayati ${ }^{3}$ \\ ${ }^{1}$ School of Postgraduate Universitas Pendidikan Indonesia \\ ${ }^{2}$ School of Postgraduate Universitas Pendidikan Indonesia \\ ${ }^{3}$ School of Postgraduate Universitas Pendidikan Indonesia \\ *Corresponding author. Email: maspur@upi.edu
}

\begin{abstract}
This study aimed at examining the connection between the subjective norm, customer green purchasing attitude, and green purchasing intention in the green hotel. The research model and methodology were based on the TRA and the TPB using explanatory approach. This research conducted online sampling through Google form application collecting 164 valid questionnaires to empirically test the hypothesis using Structural Equation Modeling (SEM). The results showed that subjective norm influenced green purchase attitude positively and significantly. In addition, the green purchase attitude directly has demonstrated a positive and significant influence on green purchase intentions. The findings firmly answered why green hotel became trend recently, which was because costumers' green subjective norms and purchase attitude strongly influenced its purchase intention for green hotels. Many of the respondent possessed postgraduate education, which highly influenced their green awareness and affected their purchasing intentions. Therefore, marketers of green hotels could use results of this study as reference to target well-educated and green aware consumers to develop good marketing campaigns.
\end{abstract}

Keywords: Green Purchase, Green Attitude, Green Intention.

\section{INTRODUCTION}

More consumers are now giving preference to environmental issues for greener alternatives to environmental benefits for goods and services [1], sometimes even additional payment [2] for products and services. The rise of this green consumerism has clearly contributed to the improvement of the purchasing, production, and service behavior of the various market sectors [3]. Customer demand for greener establishments has also increased in the hotel industry in line with the general green trend [4]. The concept of green hotels is environmentally sustainable property, a friendly environmental hotel, or other similar concepts that have been paid a lot of attention in sustainability research both theory and practice [5]. There have been many reports in the hotel industry showing the optimistic mindset of customers towards Green Hotel availability [6]; sadly, the reservation revenue for Green Hotels has not grown or dropped [7].

Researchers also argued that it was caused by a green behavior difference between customers [8]. To overcome this barrier, various researchers have therefore taken
TRA and TPB [9] as models for investigating the relationship between customer green buying behaviors and expectations. Many previous studies have confirmed that subjective norms did not relate to green purchase intentions to a significant or negligible degree [10-12]. In addition, many studies in green transactions were published in developed countries' viewpoints. Those findings may naturally not suit with developing countries environments such as Indonesia and may not help to understand the green purchasing patterns of consumers elsewhere in the green hotel industry. In view of the lack of consent in the current literature and from a different point of view above, this research aims to explain the role of attitude of Indonesian customers in predicting their intention to choose a green hotel.

A good relationship between consumer attitudes and their behavior has been found in many studies, particularly as far as green marketing is concerned [1214]. Reference [15] describes a green purchasing attitude as one person's assessment of the value of green goods, based on the mental faculties. Reference [16] argued that previous research in green procurement has shown that people generally say that they are environmentally 
conscious. While, [17] investigated the factors influencing the green buying behavior of consumers in Iran and showed a positive attitude towards green goods, which had a beneficial impact on the consumer's buying plans. Related to services, in particular accomodation, [18] explored the relationship among US consumer accommodation consumers between attitudes, subjective norms, perceived behavioral control, and consumers' visits to the green hotels. Their study has shown that the impact of behavior on the intention of visiting consumers was more significant than the other factors, and therefore the best indicator was customer intention. Recently, a research conducted by [19] supported green behavior of consumer that was positively responded by the hoteliers, which emphasized two key points in promoting the marketing of their "green hotel", which are reducing ecological damage and strengthening the promotion of green education.

The subjective norms are represented according to the normative beliefs of an individual concerning what others think he/she should and should not do [20]. The subjective norm is simply the consumer's meaning of moral duty. As an environmentally sound motivator, it can be strong [21]. For example, [22] investigated the precedent variables influencing the intention of consumers to visit green hotels in the United States, suggesting that a subjective norm affected positively the preference for green shopping and that green purchasing activity induced a positive intention to frequent green hotels. For instance, some researchers have found evidence that the general consumer decision-making system had a significant causal path from subjective norms to attitudes [23, 24].

A sample of 184 people was analyzed by [25] and showed that there was a substantial relationship between consumers subjective norms in environmental issues and their attitudes to green products. These variables also affected consumers purchasing perceptions towards green products in Malaysia. Reference [18] used an online survey to apply the theory of planned behaviour (TPB) for the green selection of customers in the Unites States hotels. It showed that the subjective norm had positive indirect impact on customers' green buying motive, while the quantitative norm positively affected green buying intentions through attitudes.

This research tried to measure the correlation between Indonesia consumer's green preferences of subjective norms and purchase attitude that lead to purchase intention of green hotels. Figure 1 shows the conceptual framework of this research.

Based on the literature and the results of previous studies, three hypotheses proposed for are:

H1: There is a positive effect of green purchase attitude on consumers' green purchase intention on green hotel selection.
$\mathrm{H} 2$ : There is a positive influence between subjective norms and attitudes of green purchases on green hotel selection.

H3: Green purchase attitudes mediate the relationship between subjective norms and green buying intentions towards green hotel selection.

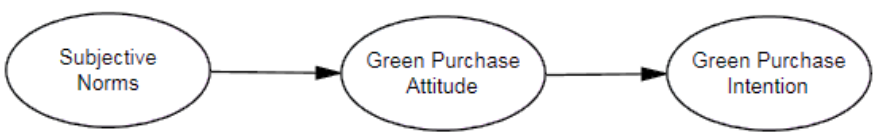

Figure 1. Conceptual Framework

\section{METHODS}

Explanatory study is used to explain the nature of the causal relationships between independent and dependent variables [26]. A survey approach has been used to gather data as it provides many benefits such as encouraging a huge number of data from a large population to be gathered in an appropriate manner [27]. Non-probability sampling approach was adopted for the result analysis. Reference [26] argued that accurate sampling frameworks of companies and organizations are difficult to obtain and to find suitable respondents in research. In addition to current sampling, the Google form application online sampling method was used to collect data samples, due to its well-known advantages, such as immediate access to a broader public, data collection irrespective of their geographical location, low costs, and better viewing of questionnaires.

A well-established questionnaire on subjective norm [28], green purchase attitude, and green purchase intention [29] was modified and employed for this research and distributed through WhatsApp application. In total, 164 questionnaires from Indonesian respondents from August to September 2019 were collected and not a single data were missing. For this analysis, the 5-point scale of Likert has been adapted. Confirmatory factor analysis (CFA) was carried out in order to test the construct validity of the proposed behavior. Structural equation modeling was then used to assess how much the suggested causal structure could explain the correlations observed between variables and estimate the magnitude of the postulated effects [26].

\section{RESULTS AND DISCUSSION}

Those 164 valid responses were collected from 90 male respondents $(54.9 \%)$ and 74 female respondents $(45.1 \%)$. Then, $48.8 \%$ of the total respondents aged 31 40 years, and $79.9 \%$ of the total respondents were married. In addition, $62.2 \%$ of respondents have obtained a postgraduate degree. 
The results showed that all items had a loading factor value higher than 0.5 , which presented a static significance [30]. These findings highlighted that all items contributed to the research construct and availability for further analysis. Model fit of the research construct showed reliable results with $\mathrm{p}$ values $0.006<$ 0.05 , RMSEA $0.059<0.8$, CFI and TLI $>0.9$ (see Figure 2) [30]. While the average variants extracted (AVE) and composite reliability (CR) values were evaluated to check the reliability of the research instrument, the results showed the AVE value $>0.5$ and CR $>0.7$, then it can be said that the value is in the good category [30].

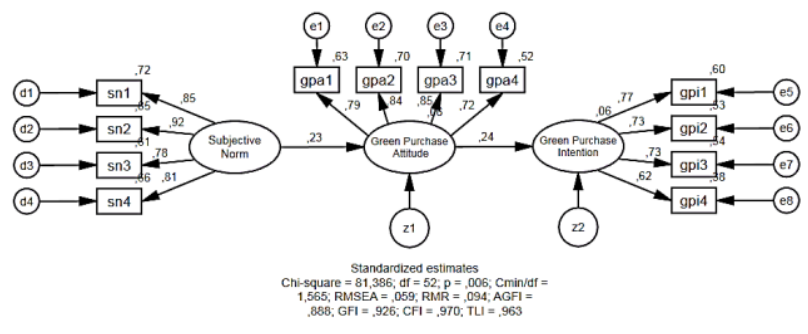

Figure 2. SEM Results

The results confirmed that subjective norm had a positive and significant influence toward green purchase attitude $(\beta=0.235, \mathrm{p}<0.01)$ Therefore, H1 was accepted. Green purchase attitude also had a positive and significant result on green purchase intention $(\beta=0.236$, $\mathrm{p}<0.01)$ and proven to mediate subjective norm and green purchase intention significantly $(\mathrm{p}<0.01)$. Therefore, $\mathrm{H} 2$ and $\mathrm{H} 3$ were accepted. Based on previous studies there have been significant positive effects on green buying intentions [22, 31] and the subjective norm in some circumstances was the largest predictor of green buying behavior among consumers [32]. This is in line with several findings for significant causal path from the subjective norm toward green purchasing attitude [18, 33].

Marketers of green hotels could use recognizable results of this study to target consumers and develop marketing campaigns, as they are distinctive from results from previous studies. This study illustrates how necessary it is to define and exploit the attitude and subjective norm for the future reference of green businesses, for hospitality marketers interested in taking advantage of the intention of consumers to maintain green hotels. Consumer attitude and subjective norm both play a major role, affecting intension. In terms of the Indonesian green marketing, consumers will have greater trust and will be ready to overcome the obstacles to the protection of green hotels if they have a positive attitude. Green hotels receiving positive or new conceptions from close friends, family, and colleagues lead to a positive green purchase attitude. Many of the respondents who have completed a post-graduate education have a high degree of green awareness and can affect their purchasing intentions.

\section{CONCLUSIONS}

Hospitality vendors should consider the importance of the subjective norm in influencing green purchase intentions to encourage their public green campaigns if consumers book their hotels. The primary limitation of this study is that the data being collected via a broad range of Indonesian networking online surveys. Though online surveys are becoming increasingly popular, there are still many recognized drawbacks in implementing this survey process. This research explored the green purchase intention of customers to select green hotels based on the concept of TPB rather than on their real buying behavior. Green purchase intention models can be a robust in a number of behavioral domains, as the current behavior of a consumer do not always the same as the particular research findings. Moreover, this study was carried out with a quite few respondents, compare with the current trends of green hotels frenzy (favoritism). The population will be better represented with a larger sample.

\section{ACKNOWLEDGMENT}

I would like to express my appreciation to SPS Universitas Pendidikan Indonesia and the GCBME 2020 committee for giving me opportunity to present this paper. As well as gratitude to my supervisors for providing valuable knowledge and supports.

\section{REFERENCES}

[1] T. Russel, "Greener purchasing: Opportunities and innovations," Routledge, 2017.

[2] C. Hagmann, J. Semeijn, and D.B. Vellenga, "Exploring the green image of airlines: Passenger perceptions and airline choice," J. of Air Transport Management, vol. 43, pp. 37-45, 2015.

[3] B. Chekima, S.A.W.S.K. Wafa, O.A. Igau, S. Chekima, and S.L. Sondoh Jr, "Examining green consumerism motivational drivers: Does premium price and demographics matter to green purchasing?," J. of Cleaner Production, vol. 112, pp. 3436-3450, 2016.

[4] S. Punitha, Y.A. Aziz, and A. Abd Rahman, "Consumers' perceptions of green marketing in the hotel industry," Asian Social Science, vol. 12, no. 1, pp. 1, 2016.

[5] Mohammed and A. Al-Swidi, "The influence of CSR on perceived value, social media and loyalty in the hotel industry," Spanish J. of Marketing - ESIC, 
vol. 23, no. 3, pp. 373-396, 2019, doi: 10.1108/SJME-06-2019-0029.

[6] C.-C. Li, T. Chang, and S.-H. Chuang, "Customer satisfaction and customer loyalty towards the green hotel: Based on cases studied in Ken-ding area in Taiwan," 13th International Conference on Service Systems and Service Management (ICSSSM), pp. 16, 2016.

[7] H. Chong and R. Verma, "Hotel sustainability: Financial analysis shines a cautious green light," Cornell Hospitality Report, vol. 13, no. 10, pp. 6-13, 2013.

[8] T. Albayrak, Ş. Aksoy, and M. Caber, "The effect of environmental concern and scepticism on green purchase behavior," Marketing Intelligence \& Planning, 2013.

[9] Ajzen, "The theory of planned behavior," Organizational Behavior and Human Decision Processes, vol. 50, no. 2, pp. 179-211, 1991.

[10]K. Chan and L. Tsang, "Promote healthy eating among adolescents: A Hong Kong study," J. of Consumer Marketing, 2011.

[11] L.C. Leonidou, C.N. Leonidou, and O. Kvasova, "Antecedents and outcomes of consumer environmentally friendly attitudes and behavior," J. of Marketing Management, vol. 26, no. 13-14, pp. 1319-1344, 2010.

[12] J. Paul, A. Modi, and J. Patel, "Predicting green product consumption using theory of planned behavior and reasoned action" J. of Retailing and Consumer Services, vol. 29, pp. 123-134, 2016.

[13]R.M. Dangelico and D. Vocalelli, "Green Marketing: An analysis of definitions, strategy steps, and tools through a systematic review of the literature," J. of Cleaner Production, vol. 165, pp. 1263-1279, 2017.

[14] Ali and I. Ahmad, "Environment friendly products: Factors that influence the green purchase intentions of Pakistani consumers" Pakistan J. of Engineering, Technology \& Science, vol. 2, no. 1, 2016.

[15]P. Hartmann, V.A. Ibáñez, and F.J.F. Sainz, “Green branding effects on attitude: Functional versus emotional positioning strategies" Marketing Intelligence \& Planning, 2005.

[16] M. Laroche, J. Bergeron, and G. Barbaro-Forleo, "Targeting consumers who are willing to pay more for environmentally friendly products," J. of Consumer Marketing, vol. 18, no. 6, pp. 503-520, 2001.
[17]H. Vazifehdoust, M. Taleghani, F. Esmaeilpour, and K. Nazari, "Purchasing green to become greener: Factors influence consumers' green purchasing behavior," Management Science Letters, vol. 3, no. 9, pp. 2489-2500, 2013.

[18] H. Han, L.-T.J. Hsu, and C. Sheu, "Application of the theory of planned behavior to green hotel choice: Testing the effect of environmental friendly activities," Tourism Management, vol. 31, no. 3, pp. 325-334, 2010.

[19]C.-T. Ting, C.-M. Hsieh, H.-P. Chang, and H.S.Chen, "Environmental consciousness and green customer behavior: The moderating roles of incentive mechanisms," Sustainability, vol. 11, no. 3, pp. 819, 2019, doi: 10.3390/su11030819.

[20] M. Fishbein and I. Ajzen, Understanding Attitudes and Predicting Social Behavior, 1980.

[21]H. Choi, J. Jang, and J. Kandampully, “Application of the extended VBN theory to understand consumers' decisions about green hotels" International J. of Hospitality Management, vol. 51, pp. 87-95, 2015.

[22]H. Han, and H.J. Yoon, "Hotel customers' environmentally responsible behavioral intention: Impact of key constructs on decision in green consumerism," International J. of Hospitality Management, vol. 45, pp. 22-33, 2015.

[23] Tarkiainen, and S. Sundqvist, "Subjective norms, attitudes and intentions of Finnish consumers in buying organic food," British Food J., 2005.

[24] Al-Swidi, S.M.R. Huque, M.H. Hafeez, and M.N.M. Shariff, "The role of subjective norms in theory of planned behavior in the context of organic food consumption.” British Food J., 2014)

[25] T.B. Chen and L.T. Chai, "Attitude towards the environment and green products: Consumers' perspective" Management Science and Engineering, vol. 4, no. 2, pp. 27-39, 2010.

[26] J.F. Hair, Essentials of Business Research Methods, ME Sharpe, 2015.

[27]E. Bell, A. Bryman, and B. Harley, Business Research Method, Oxford university press, 2018.

[28] Grønhøj, and J. Thøgersen, "Action speaks louder than words: The effect of personal attitudes and family norms on adolescents' pro-environmental behavior," J. of Economic Psychology, vol. 33, no. 1, pp. 292-302, 2012.

[29] Y. Joshi and Z. Rahman, "Factors affecting green purchase behaviour and future research directions," 
International Strategic Management Review, vol. 3, no. 1-2, pp. 128-143, 2015.

[30] J.F. Hair, M. Gabriel, and V. Patel, "AMOS covariance-based structural equation modeling (CBSEM): Guidelines on its application as a marketing research tool," Brazilian J. of Marketing, vol. 13, no. $2,2014$.

[31]M.-F. Chen and P.-J. Tung, "Developing an extended theory of planned behavior model to predict consumers' intention to visit green hotels," International J. of Hospitality Management, vol. 36, pp. 221-230, 2014.
[32] S.B. Ko, and B. Jin, "Predictors of purchase intention toward green apparel products," J. of Fashion Marketing and Management: An International J., 2017.

[33] E. Kim, S. Ham, I.S. Yang, and J.G. Choi, "The roles of attitude, subjective norm, and perceived behavioral control in the formation of consumers' behavioral intentions to read menu labels in the restaurant industry," International J. of Hospitality Management, vol. 35, pp. 203-213, 2013. 